International Journal of

Supply Chain

Management

(IJSCM)

Influence of Public Private Partnerships on Performance of

Projects Among State Corporations in Kenya

Mary Mkamburi Mwatika and Dr. Makori Moronge

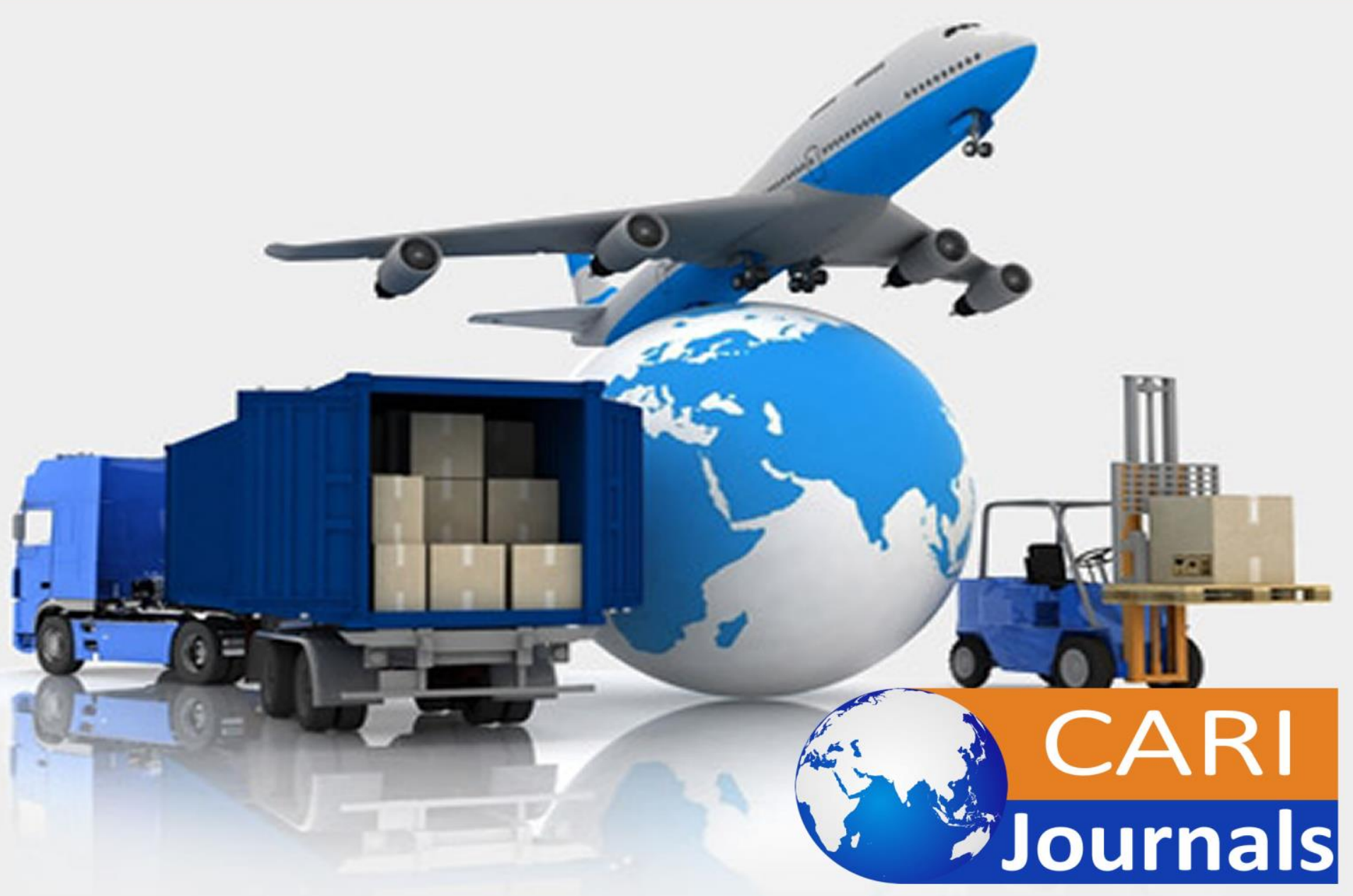




\title{
Influence of Public Private Partnerships on Performance of Projects Among State Corporations in Kenya
}

\author{
1*Mary Mkamburi Mwatika \\ Post Graduate Student: Department of Procurement and Logistics, \\ Jomo Kenyatta University of Agriculture and Technology \\ *Corresponding Author’s E-mail: mkamburi2002@yahoo.com \\ ${ }^{2 *}$ Dr. Makori Moronge \\ Lecturer, Department of Procurement and Logistics \\ Jomo Kenyatta University of Agriculture and Technology
}

\begin{abstract}
Purpose: The overall objective of this study was to examine the influence of public private partnerships on performance of projects among state corporations in Kenya.

Methodology: This research study adopted a descriptive research design approach. The study preferred this method because it allowed an in-depth study of the subject. The study employed stratified random sampling technique in coming up with a sample size of 127 respondents from a total of 187 target population. Structured and semi structured questionnaires were used to collect data. Data gathered from the questionnaires administered was analyzed by the help of Ms Excel and SPSS version 22, while output was presented inform of frequency tables and charts. The study used both descriptive and inferential statistics to show the relationship between variables.

Results and conclusion: The regression equation above has established that taking all factors into account (policy framework, feasibility studies, value for money and risk mitigation) constant at zero, performance of projects among state corporations will be an index of 1.967. The study found that a unit increase in feasibility studies will lead to a 0.358 increase in the performance of PPP projects among state corporations. The P-value was 0.000 and hence the relationship was significant since the $\mathrm{p}$-value was lower than 0.05 . The findings presented also shows that taking all other independent variables at zero, a unit increase in policy framework will lead to a 0.132 increase in the performance of PPP projects among state corporations. The P-value was 0.02 which is less 0.05 and thus the relationship was significant. In addition, the study found that a unit increase in value for money will lead to a 0.121 increase in the performance of PPP projects among state corporations. The P-value was 0.000 and thus the relationship was significant because the $\mathrm{p}$ value was less than 0.05 . The study also found that a unit increase in risk mitigation will lead to a 0.05 increase in performance of PPP projects among state corporations. The P-value was 0.03 , which is less than 0.05 and thus the relationship was significant. The findings of the study indicated that policy framework, feasibility studies, value for money and risk mitigation have a positive relationship with performance of projects among state corporations in Kenya.
\end{abstract}


International Journal of Supply Chain and Logistics

ISSSN 2520-3983 (Online)

Vol. 4, Issue No.2, pp 52 - 79, 2020

$\underline{\text { www.carijournals.org }}$

Unique contribution to theory, practice and policy: The study recommended that public institutions should embrace public private partnerships so as to improve performance of projects among state corporations and further researches should to be carried out in other public institutions to find out if the same results can be obtained.

Keywords: Policy framework, feasibility studies, value for money and risk mitigation

\subsection{INTRODUCTION}

According to the Public Procurement and Disposal (Public Private Partnerships) Regulations, (2013), a Public Private Partnership (PPP) is an agreement between a procuring entity (government ministries and parastatals) and a private party under which the private party undertakes to perform a public function or provide a service on behalf of the procuring entity. The private party receives a benefit for performing the function, either by way of compensation from a public fund, charges or fees collected by the private party from users or customers of a service provided to them or a combination of such compensation and such charges or fees.

PPP is a long-term contractual agreement between a public body and a private partner (or a consortium of private firms) in which the private party provides a public service and assumes substantial risk in the project for a return on their investment. The terrain of public project procurement is gradually changing in many countries as a result of innovative procurement approaches that include PPP's (Dada, 2009). The traditional procurement method has been the most common it has, however, suffered criticisms as a result of perceived drawbacks and limitations (Ojo, 2009).

Zhang (2014) acknowledged the emergence and growing popularity of innovative procurement approaches for infrastructure development through PPP's including limited time privatization based on the concept of concession or build-operate-transfer (BOT) and other variants. PPP approach can have a strong positive effect on the economic life of any country and government is no longer considered the sole provider of public works and services (Montanheiro, 2008). PPP's through the private finance initiative (PFIs) have been recognized as important approaches to solving problems for governments in providing infrastructure systems (Ho, 2016).

In general, PPP's involves the transfer of responsibility (from the public sector to the private sector) for the design, building, finance and operation of public sector assets, such as buildings, infrastructure, equipment and other associated facilities, according to an agreed concession period (normally 25 to 30 years). The private party will raise its own funds to finance all or part of the assets that will deliver the services based on the agreed performance specification. In turn, the public sector will compensate the private party for these services through a monthly lease payment, or, in some PPP projects, part of the payment may flow from the public users directly (Ismail, 2013).

This uptake in PPP's by governments especially in developing countries can be attributed to increasing pressure from their citizens, civil society organizations, and the media to provide sufficient infrastructure services such as transportation, energy and communications (Udechukwu, 2012). The pressure was also felt from the United Nations (UN) Sustainable Development Goals 
International Journal of Supply Chain and Logistics

ISSSN 2520-3983 (Online)

Vol. 4, Issue No.2, pp 52 - 79, 2020

$\underline{\text { www.carijournals.org }}$

(SDGs), under which country development and progress is monitored. Hence, confronted with limited funds but growing demand for infrastructure services, governments in both developed and developing countries have begun to view PPP's as a way to expedite critical infrastructure that may otherwise not be built (Agere, 2010).

\subsection{Problem Statement}

Kenya's long-term development agenda spelt out in the vision 2030, targets an annual growth rate of above $10 \%$ with an investment rate of $30 \%$, state corporations are key drivers in this projected growth. State corporations accounted for $20 \%$ of the country's GDP, provided employment to about 4 million persons (GoK, 2016). However, state corporations in Kenya have been experiencing a myriad of problems including misappropriation and blatant mismanagement of the meager resources (Regional Economic Outlook, 2013).

At least 30 out of the 46 countries in Sub-Saharan Africa are currently facing a debilitating infrastructural crisis (IMF, 2015). The crisis is fuelled in part by growing demand for infrastructural facilities such as electricity, roads and sewer systems consumption expected to grow at a yearly rate of $2.6 \%$ (IEA, 2016). At the same time, rates of urbanization have been increasing at $3.5 \%$ a year, industrial and manufacturing sectors expanding as well, thus adding to the growing demand for infrastructural facilities (UNEP, 2014).

According to an annual customer satisfaction survey by some of the state corporations in 2012 and 2013 , carried out by a contracted vendor, it is notable that the satisfaction percentage index has been fluctuating towards more and more dissatisfaction, that is, 69\% and 66\% respectively (Makau, 2014). On the other hand, the corporations face a major challenge in controlling the overall sourcing costs because of the constant increase due the lack of much needed PPP's input; this is evident by posting a decrease in profit prior to tax noted (OECD, 2010).

The problem of poor productivity and the absorption of excessive portion of the budget among state corporations represents a drain on the exchequer meager resources and also results into non delivery on intended services (Africa Infrastructure Country Diagnostic, 2009). This has a negative implication on the welfare of Kenyan citizens and may also imply that Vision 2030 is not met, this where the PPP's specialized input should come in (KIPPRA, 2016).

Studies have done world over, in the UK, previous research by Griffin, Foster and Halpin (2014) on the survey of the influence of PPP's usage in public projects shows that global state corporations' use of the PPP's is high, while in Kenya, previous research by Githumbi (2013) on usage, show that only $33 \%$ of state corporations have implemented PPP's as a strategy to improving services. This has left an evident knowledge gap, which the study intends to bridge by determining the influence of public private partnerships on performance of projects among state corporations in Kenya. It is against this back drop that this study sets out to investigate the influence of public private partnerships on performance of projects among state corporations in Kenya. 
International Journal of Supply Chain and Logistics

ISSSN 2520-3983 (Online)

Vol. 4, Issue No.2, pp 52 - 79, 2020

www.carijournals.org

\subsection{Objectives of the Study}

i. To examine the influence of policy framework on performance of projects among state corporations in Kenya.

ii. To determine the influence of feasibility studies on performance of projects among state corporations in Kenya.

iii. To assess the influence of the concept of value for money on performance of projects among state corporations in Kenya.

iv. To examine the influence of risk mitigation on performance of projects among state corporations in Kenya.

\subsection{LITERATURE REVIEW}

\subsection{Public Value Theory}

Public value theory was formulated by Moore (1995) to provide public sector managers with a greater understanding of the constraints and opportunities within which they work, and the challenge to create publically valuable outcomes. A decade later, Benington and Moore (2010) improves the argument by opining that public value theory envisages a manager's purpose as going beyond implementation of policy and adherence to institutional norms.

It includes seeking out opportunities to make significant improvements to the lives of the public. Moore (1995) also notes that public value theory articulates a more proactive and strategic role for public sector managers who seek to discover, define and produce public value, instead of just devising means for achieving mandated purposes. So, rather than procuring projects using traditional procurement methods, a public sector client might decide to pursue a project as PPP as long as they can account for cost and saving throughout the project lifetime (Moralos \& Amekudzi, 2008).

According to Constable, Passmore and Coats (2008) unlike private enterprise, organizations providing public services are directly accountable to citizens and their democratic representatives. This theory was important in explaining value for money when applied to a PPP, which means that a PPP is supposed to bring larger value for the money that the public sector spends, compared to when services are provided 'in-house' (by public agencies) or when services are contracted out to a private company.

The underlying logic is that using a PPP will make sense, in the opinion of many, only if a PPP can deliver public sector services cheaper and better, meaning with smaller costs as opposed to other options, and with improved quality (and other enhanced output features) as opposed to other options. If value for money is not there, for example, when government costs of the PPP project are higher than costs involved in the direct public service provision, a PPP should not be employed to achieve public procurement when the private sector pays a comparatively economic price for the highest possible specification capable of meeting the expected goals. 


\subsection{PUBLIC PRIVATE PARTNERSHIPS}

\subsubsection{Policy Framework}

A policy framework encompasses the laws, regulations and policies that are put in place to govern an organization or an activity. The PPP policy framework clearly covers the whole scope of PPP, all stages of the procurement process, methods of procurement, ethics and transparency (Thai, 2009). Robert (2013), states that a good public procurement policy framework is based on the principles of openness and transparency, fair competition, impartiality, and integrity. According to American Bar Association (2010), a sound public procurement system needs to have good procurement laws and regulations.

\subsubsection{Feasibility Studies}

The term feasible describes an action or event that is likely, probably or possible to happen or achieved. A feasibility study is the total of the actions you take and the questions you ask to determine whether an idea, thought or plan is likely to succeed. An effective study can guide you on whether you should move forward with your idea, refine it, or scrap it altogether and go back to the drawing board (Lohrey, 2013).

\subsubsection{The Concept of Value for Money}

Value for money means delivering the required public services with the optimal cost and benefits (Akintoye \& Chinyio, 2015). It is a key indicator used by the public sector to assess whether a PPP project will offer better value over other conventional procurement options. Akintoye and Chinyio (2015) stated that achieving value for money should be the benchmark strategic objective of PPP projects.

\subsubsection{Risk Mitigation}

PPP projects usually involve higher degree of risks than conventional procurement, since they are characterized by many stakeholders, a huge amount of investments and long concession periods (Wei-hua \& Da-shuang, 2016). Therefore, PPP projects involve not only risks that are projectrelated but also risks that depend on the inner characteristics of PPP as a procurement method. 


\subsection{CONCEPTUAL FRAMEWORK}

Independent Variables

\section{Dependent Variable}

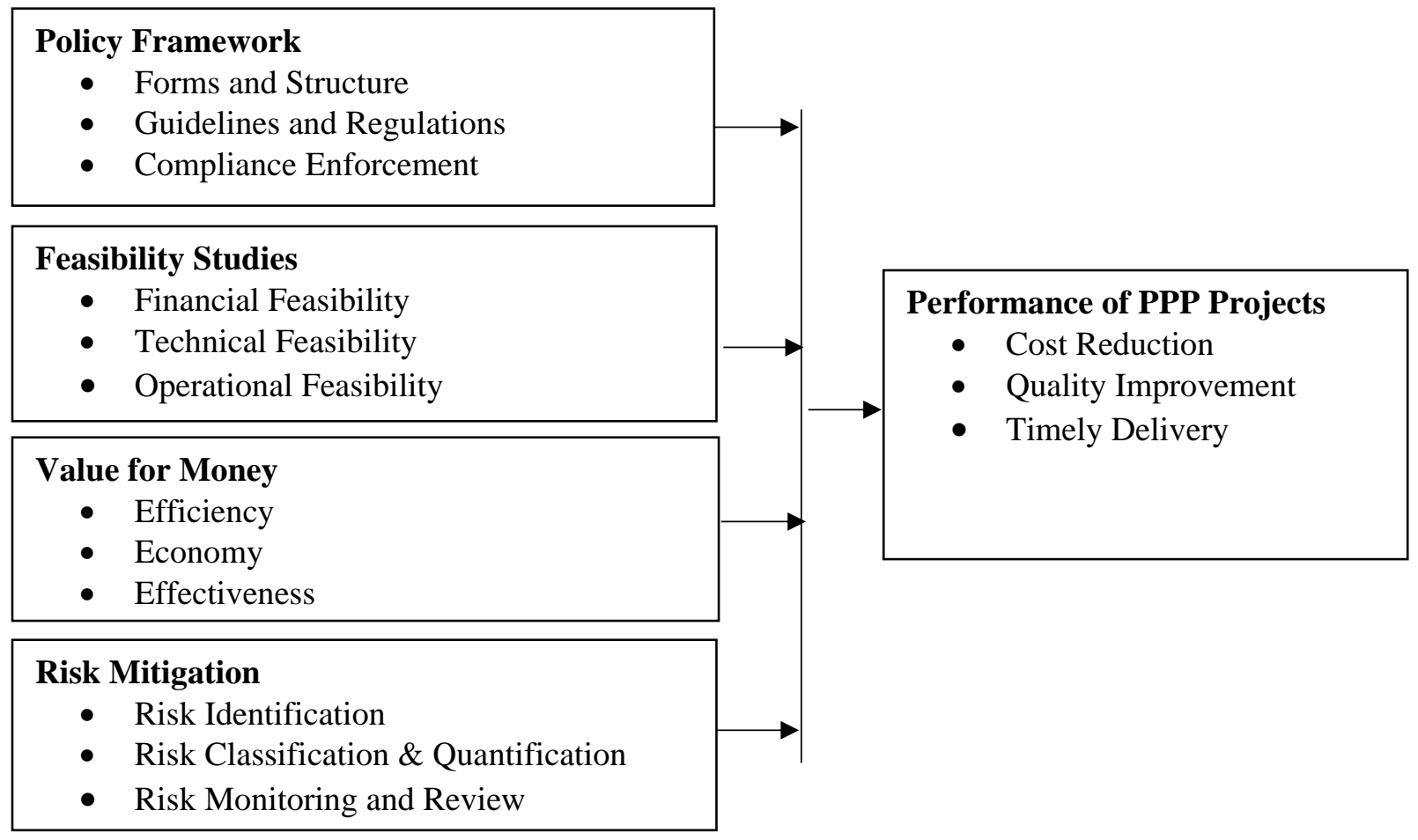

Figure 1: Conceptual framework

\subsection{METHODOLOGY}

This research study adopted a descriptive research design approach. The study preferred this method because it allowed an in-depth study of the subject. The study employed stratified random sampling technique in coming up with a sample size of 127 respondents from a total of 187 target population. Structured and semi structured questionnaires were used to collect data. Data gathered from the questionnaires administered was analyzed by the help of Ms Excel and SPSS version 22, while output was presented inform of frequency tables and charts. The study used both descriptive and inferential statistics to show the relationship between variables. 
International Journal of Supply Chain and Logistics

ISSSN 2520-3983 (Online)

Vol. 4, Issue No.2, pp 52 - 79, 2020

wWw.carijournals.org

\subsection{RESULTS FINDINGS}

\subsection{Introduction}

This chapter presents results arising from the analysis of data collected using questionnaires.

\subsection{Response Rate}

A sample of 127 respondents were approached using questionnaires that allowed the researcher to drop the questionnaire to the respondents and then collect them at a later date when they had filled the questionnaires. A total of 127 questionnares were distributed to the sampled heads of procurement. Out of the population covered, 110 were responsive respresenting a response rate of $87 \%$. This was above the $50 \%$ which is considered adequate in descriptive statistics according to (Cooper, 2016).

Table 1: Response Rate of Respondents

\begin{tabular}{lll}
\hline Response & Frequency & Percentage \\
\hline Actual Response & 110 & $87 \%$ \\
Non-Response & 17 & $13 \%$ \\
Total & $\mathbf{1 2 7}$ & $\mathbf{1 0 0 \%}$ \\
\hline
\end{tabular}

\subsection{Pilot Study}

The cronbach's alpha was computed in terms of the average inter-correlations among the items measuring the concepts. The rule of thumb for cronbach's alpha is that the closer the alpha is to 1 the higher the reliability (Trochin, 2013). A value of at least 0.7 is recommended. Cronbach's alpha is the most commonly used coefficient of internal consistency and stability. Consistency indicated how well the items measuring the concepts hang together as a set. Cronbach's alpha was used to measure realibilty. This was done on the four objectives of the study. The higher the coefficient, the more reliable is the test.

Table 2 Reliability Results

\begin{tabular}{lllll}
\hline Variable & No. of Items & Respondents & $\boldsymbol{\alpha}=$ Alpha & Comment \\
\hline Policy Framework & 9 & 13 & 0.893 & Reliable \\
Feasibility Studies & 9 & 13 & 0.987 & Reliable \\
Value for Money & 9 & 13 & 0.974 & Reliable \\
Risk Mitigation & 9 & 13 & 0.976 & Reliable \\
\hline
\end{tabular}




\subsection{Demographic Information}

This section presented the personal details of the respondents.

\subsubsection{Distribution of Respondents by Gender}

The study determined the gender distribution of the respondents. The results summarized in the figure below. The result in figure 2 revealed that majority of the respondent $(58 \%)$ indicated that they were male, while only $(42 \%)$ of the respondent indicated that they were female. The statistics may raise the issue of gender equity in public private partnership among state corporations in Kenya, but that is outside the scope of this study. A study on South African organizations found that women and men do not differ in their ability to perform tasks, but rather bring a different perspective to performance of projects (Associate, 2017).

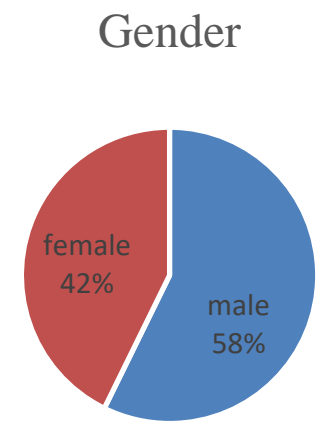

\section{Figure 2: Distribution of Respondents by Gender}

\subsubsection{Distribution of Respondents by Age}

The study also determined the age of the respondents. The results are submitted in figure 3 where the majority 58\% were 31-40 years. Respondents aged between 41-50 years were $29 \%$. Respondents above 50 years accounted years accounted for 13\%. Again, this shows that those interviewed are adults capable of making independent judgments and the results of a research process involving them is deemed to be valid.

The findings are in agreement with those of Dunn (2010) who established that there are two natural age peaks of the late 30 s to early 40 s which correlated to employee performance and the performance of public private partnership projects among state corporations. 
International Journal of Supply Chain and Logistics

ISSSN 2520-3983 (Online)

Vol. 4, Issue No.2, pp 52 - 79, 2020

www.carijournals.org

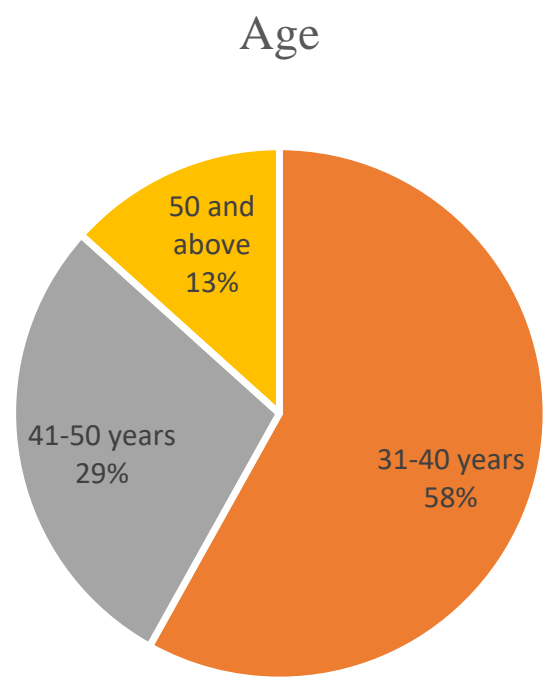

Figure 3: Distribution of Respondents by Age

\subsubsection{Distribution of Respondents by Level of Education}

The respondents were asked to state their highest level of education and the results were as captured in figure 4 . The result further revealed that $(87 \%)$ of the respondent indicated that their academic qualification was up to degree level. The result also showed that only (13\%) of the respondent had masters' level. These findings concur those of Syuhaida (2009) who established that majority of who run public private partnership projects in the state corporations are highly educated and that there is evidence linking education and performance of public private partnership projects.

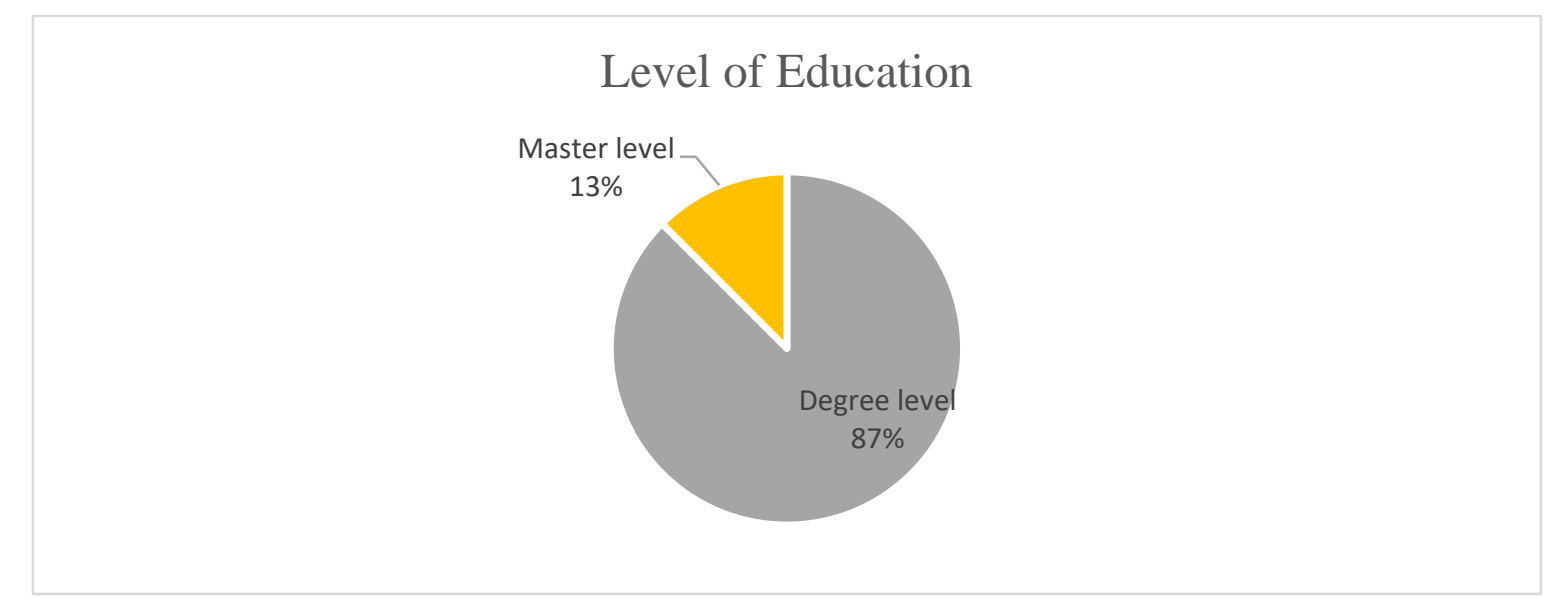

Figure 4: Distribution of Respondents by Level of Education 


\subsubsection{Distribution of Respondents by Length of Service}

The study determined the number of years the respondents had good performance in public private partnership in projects among state corporations in Kenya. The respondents were asked to indicate their work duration. The result revealed that majority of the respondents (50\%) indicated that their work duration was 5-8 years. The result also showed that $(27 \%)$ of the respondent indicated that their work duration was 9 years and above. The result further revealed that $(23 \%)$ of the respondent indicated that their work duration was 3-5 years. The findings of the study are in tandem with literature review by Pitt (2016) who indicated that a duration and experience of employee helps him or her to have better knowledge and skills which contribute to better performance in public private partnership projects.

\section{Length of Service}

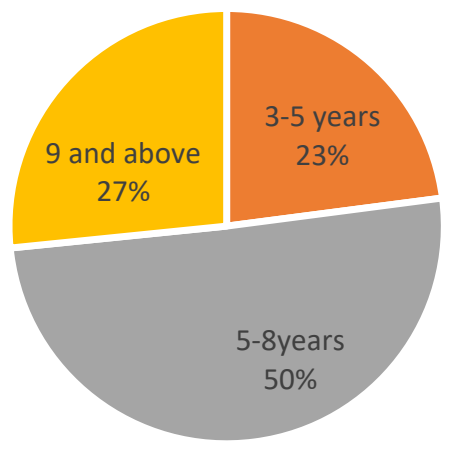

Figure 5: Distribution of Respondents by Length of Service

\subsection{Descriptive Statistics}

\subsubsection{Policy Framework}

The first objective of the study was to examine the influence of policy framework on performance of projects among state corporations in Kenya. The respondents were asked to indicate to what extent policy framework influence performance of projects among state corporations. Results indicated that majority of the respondents $46 \%$ agreed that it was effective, $41 \%$ said that it was very effective, $8 \%$ said it was ineffective, somehow effective was at $5 \%$. 
International Journal of Supply Chain and Logistics

ISSSN 2520-3983 (Online)

Vol. 4, Issue No.2, pp 52 - 79, 2020

www.carijournals.org

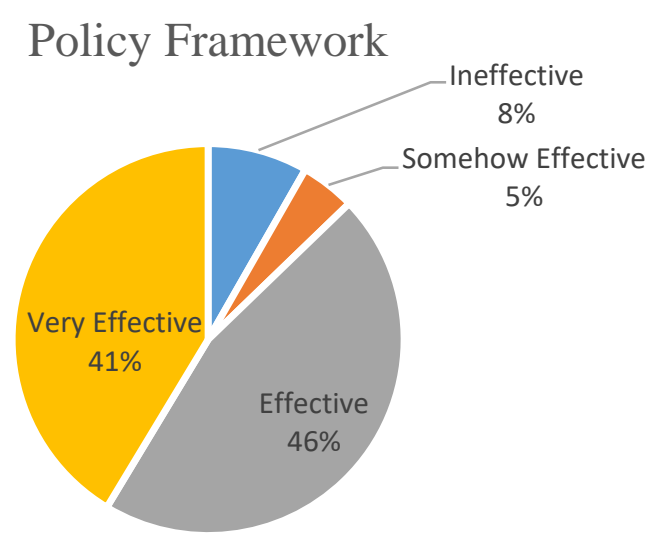

Figure 6: Policy Framework

The respondents were also asked to comment on statements regarding policy framework influence on performance of projects among state corporations in Kenya. The responses were rated on a Likert scale and the results presented in Table 3 below. It was rated on a 5 point Likert scale ranging from; $1=$ strongly disagree to $5=$ strongly agree. The scores of ' strongly disagree' and 'disagree' have been taken to represent a statement not agreed upon, equivalent to mean score of 0 to 2.5. The score of 'neutral' has been taken to represent a statement agreed upon, equivalent to a mean score of 2.6 to 3.4. The score of 'agree' and 'strongly agree' have been taken to represent a statement highly agreed upon equivalent to a mean score of 3.5 to 5 .

The result in table 3 revealed that majority of the respondents with a mean of (3.86) agreed with the statement that forms and structures of PPP's have a significant influence on cost reduction. The measure of dispersion around the mean of the statements was 0.928 indicating the responses were varied. The result revealed that majority of the respondents as indicated by a mean of (3.85) agreed with the statement that guidelines and regulations of PPP's have a significant influence on cost reduction. The standard deviation for the statement was 0.883 showing a variation. The result revealed that majority of the respondent (3.83) agreed with the statement that compliance enforcement of PPP's rules have a significant influence on cost reduction. The results were varied as shown by a standard deviation of 0.906 .

The result revealed that majority of the respondents as shown by a mean of (4.47) indicated that they agreed with the statement that forms and structures of PPP's have a significant influence on quality improvement. The responses were varied as measured by standard deviation of 0.501 . The result revealed that majority of the respondents with a mean of (4.44) indicated that they agreed with the statement that guidelines and regulations of PPP's have a significant influence on quality improvement. The responses were varied as measured by standard deviation of 0.656 . The result revealed that majority of the respondents (4.47) indicated that they agreed with the statement that compliance enforcement of PPP's rules have a significant influence on quality improvement. The responses were varied as measured by standard deviation of 0.544 . 
The result revealed that majority of the respondents (4.44) indicated that they agreed with the statement that forms and structures of PPP's have a significant influence on timely delivery. The responses were varied as measured by standard deviation of 0.752 . The result showed that majority of the respondents (4.02) indicated that they agreed with the statement that guidelines and regulations of PPP's have a significant influence on timely delivery. The responses were varied as measured by standard deviation of 0.826 . Further, the results indicated that a majority of the respondents (4.4) agreed with the statement that compliance enforcement of PPP's of rules have a significant influence on timely delivery. There was a standard deviation of 0.717 indicating a variation of responses. The average response for the statements on policy framework was 4.19. The findings agree with Montanheiro, (2008) that a good policy frameworkis necessary for the performance of public private partnerships.

Table 3: Policy Framework

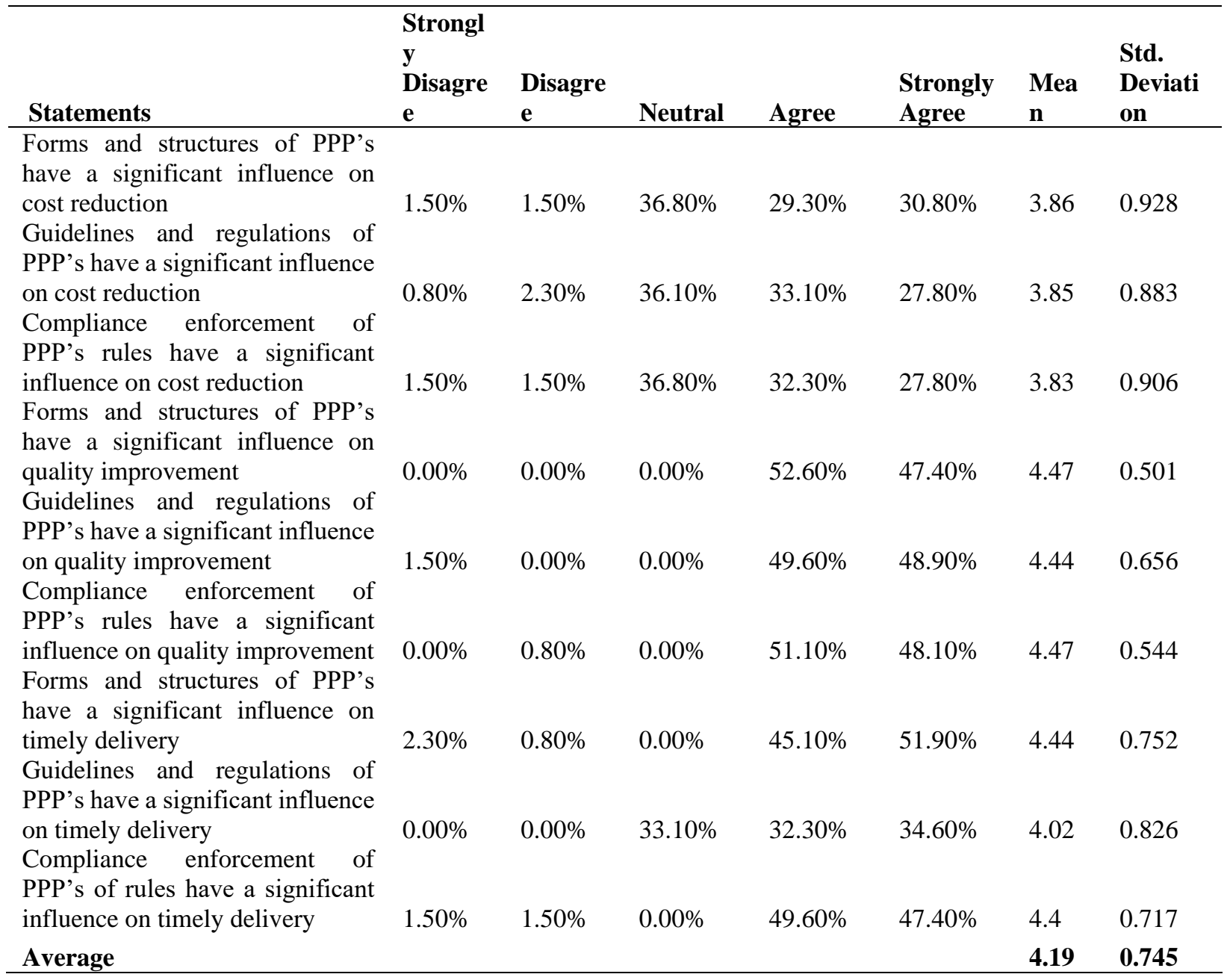


International Journal of Supply Chain and Logistics

ISSSN 2520-3983 (Online)

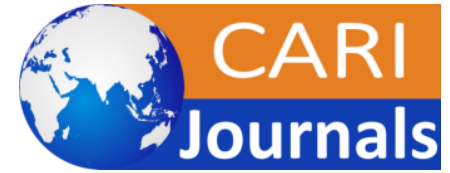

Vol. 4, Issue No.2, pp 52 - 79, 2020

WWW.carijournals.org

\subsubsection{Feasibility Studies}

There was also need to examine the influence of performance of projects among state corporations in Kenya. The respondents were also asked to comment on statements regarding how feasibility studies influenced performance of public private partnership projects in Kenya. Results showed that $49 \%$ of respondents indicated it was effective, $36 \%$ that it was very effective, $9 \%$ ineffective while $6 \%$ somehow effective.

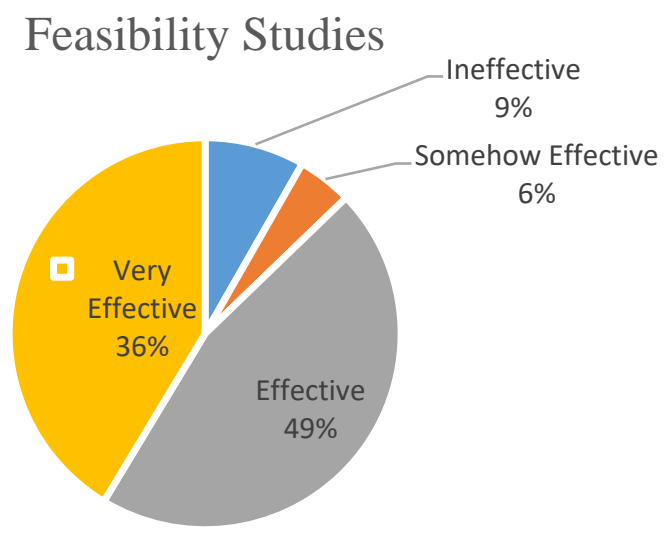

\section{Figure 7: Feasibility Studies}

The result in table 4 revealed that majority of the respondent (4.56) agreed with the statement that financial feasibility has a significant influence on cost reduction. The responses were varied as shown by a standard deviation of 0.499 . The result revealed that majority of the respondent (4.48) agreed with the statement that technical feasibility have a significant influence on cost reduction. The responses were varied as shown by a standard deviation of 0.502 . The result revealed that majority of the respondent (4.39) agreed with the statement that operational feasibility has a significant influence on cost reduction. The responses were varied as shown by a standard deviation of 0.672 .

The result further revealed that majority of the respondent (4.44) agreed with the statement that financial feasibility has a significant influence on quality improvement. The responses were varied as shown by a standard deviation of 0.742 . The result further revealed that majority of the respondent (4.51) agreed with the statement that technical feasibility has a significant influence on quality improvement. Responses were varied as shown by a standard deviation of 0.502 . The result further revealed that majority of the respondent (4.47) agreed with the statement that operational feasibility has a significant influence on quality improvement. Responses were varied as shown by a standard deviation of 0.501 .

The result revealed that majority of the respondent (4.37) agreed with the statement that financial feasibility has a significant influence on timely delivery. The responses were varied as shown by a standard deviation of 0.691 . The result revealed that majority of the respondent (4.5) agreed with the statement that technical feasibility have a significant influence on timely delivery. The 
International Journal of Supply Chain and Logistics

ISSSN 2520-3983 (Online)

Vol. 4, Issue No.2, pp 52 - 79, 2020

WwW.carijournals.org

responses were varied as shown by a standard deviation of 0.502 . The result revealed that majority of the respondent (4.51) agreed with the statement that operational feasibility has a significant influence on timely delivery. The responses were varied as shown by a standard deviation of 0.502 . The average response for the statements on feasibility studies was 4.47 . The findings agree with Mwaengo (2012) that feasibility studies are necessary for the performance of public private partnerships projects.

\section{Table 4: Feasibility Studies}

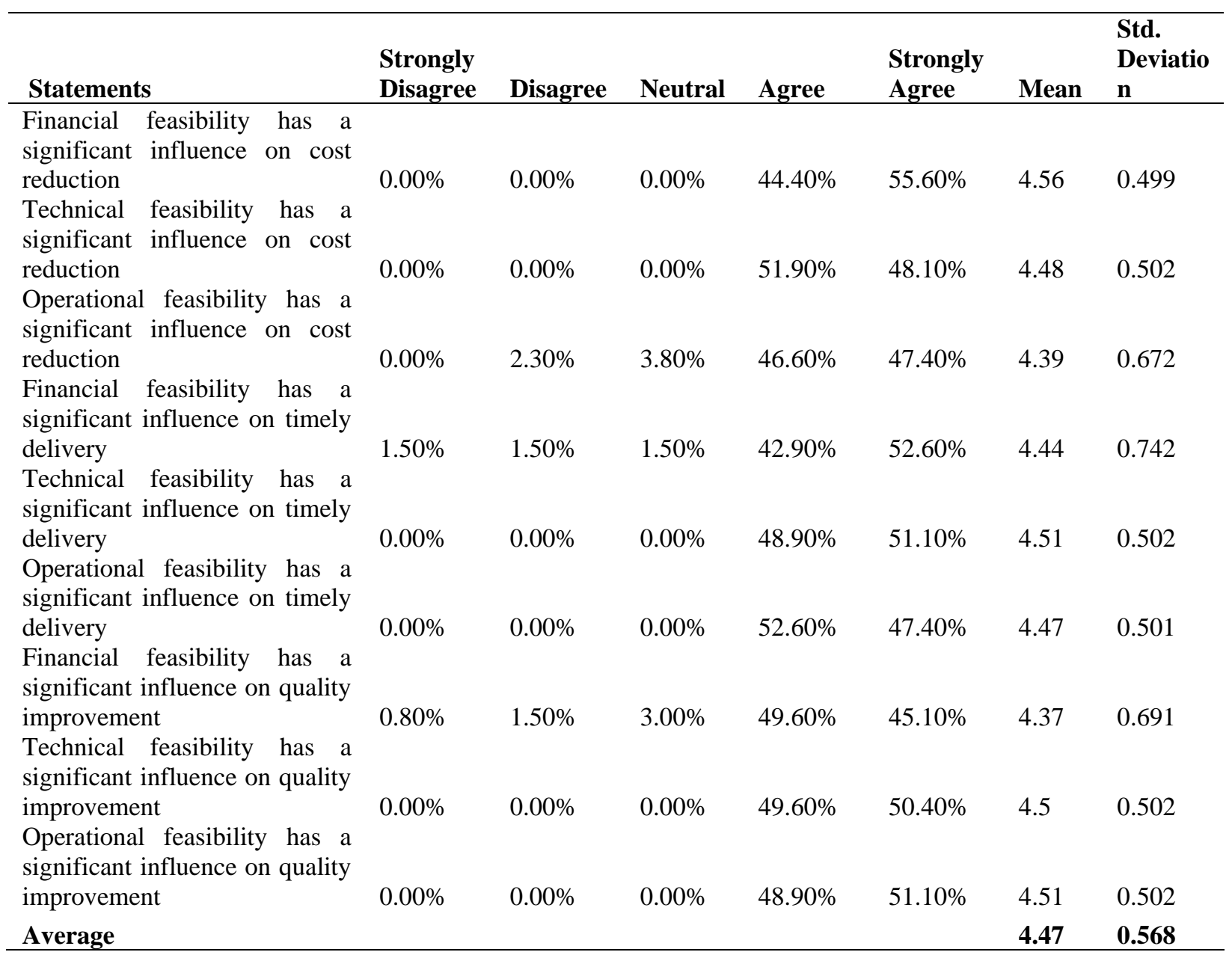

\subsubsection{Value for Money}

There was also need to assess the influence of value for money on performance of projects among state corporations in Kenya as the third objective. The respondents were asked to comment on extent of value for money influence on performance public private partnership projects in Kenya. Results indicated that majority of the respondents $50 \%$ agreed that it was effective, $42 \%$ said that it was very effective, $4 \%$ said it was somehow effective and ineffective at $4 \%$. 
International Journal of Supply Chain and Logistics

ISSSN 2520-3983 (Online)

Vol. 4, Issue No.2, pp 52 - 79, 2020

www.carijournals.org

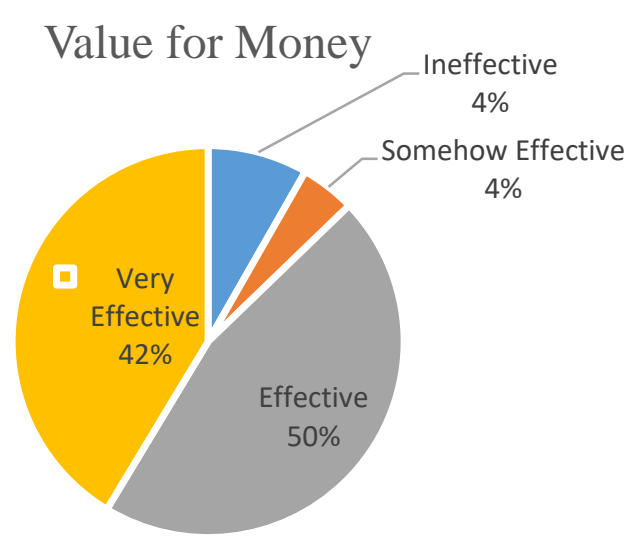

Figure 7: Value for Money

The respondents were asked to indicate their levels of agreement on statements regarding value for money. The results in table 5 revealed that majority of the respondent (4.14) agreed with the statement that efficiency in public private partnerships has a significant influence on cost reduction. The responses were varied as shown by the standard deviation of 0.818 . The result revealed that majority of the respondent (3.87) agreed with the statement that economy in public private partnerships has a significant influence on cost reduction. The measures of dispersion around the mean were 0.783 . The result revealed that majority of the respondent (3.86) agreed with the statement that effectiveness in public private partnerships has a significant influence on cost reduction. The measures of dispersion around the mean were 0.955 .

The result revealed that majority of the respondent (3.98) agreed with the statement that efficiency in public private partnerships has a significant influence on quality improvement. The measures of dispersion around the mean were 0.802 . The result revealed that majority of the respondent (3.82) agreed with the statement that economy in public private partnerships has a significant influence on quality improvement. The measures of dispersion around the mean were 1.029. The result revealed that majority of the respondents as shown by a mean of (4) indicated that they agreed with the statement that effectiveness in public private partnerships has a significant influence on quality improvement. The responses were varied as measured by standard deviation of 0.816 .

The result revealed that majority of the respondents with a mean of (2.86) indicated that they agreed with the statement that efficiency in public private partnerships has a significant influence on timely delivery. The responses were varied as measured by standard deviation of 1.476. The result revealed that majority of the respondents (4.44) indicated that they agreed with the statement that economy in public private partnerships has a significant influence on timely delivery. The responses were varied as measured by standard deviation of 0.498 . The result revealed that majority of the respondents (4.53) indicated that they agreed with the statement that effectiveness in public private partnerships has a significant influence on timely delivery. The responses were varied as measured by standard deviation of 0.501 . The average response for the statements on participative style of leadership was 3.94. The findings agree with Lakomy-Zinowik (2017) that 
International Journal of Supply Chain and Logistics

ISSSN 2520-3983 (Online)

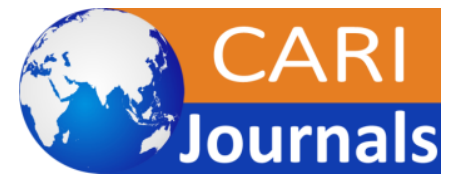

Vol. 4, Issue No.2, pp 52 - 79, 2020

WwW.carijournals.org

observing if each activity has value for money is necessary for the performance of public private partnerships projects.

Table 5: Value for Money

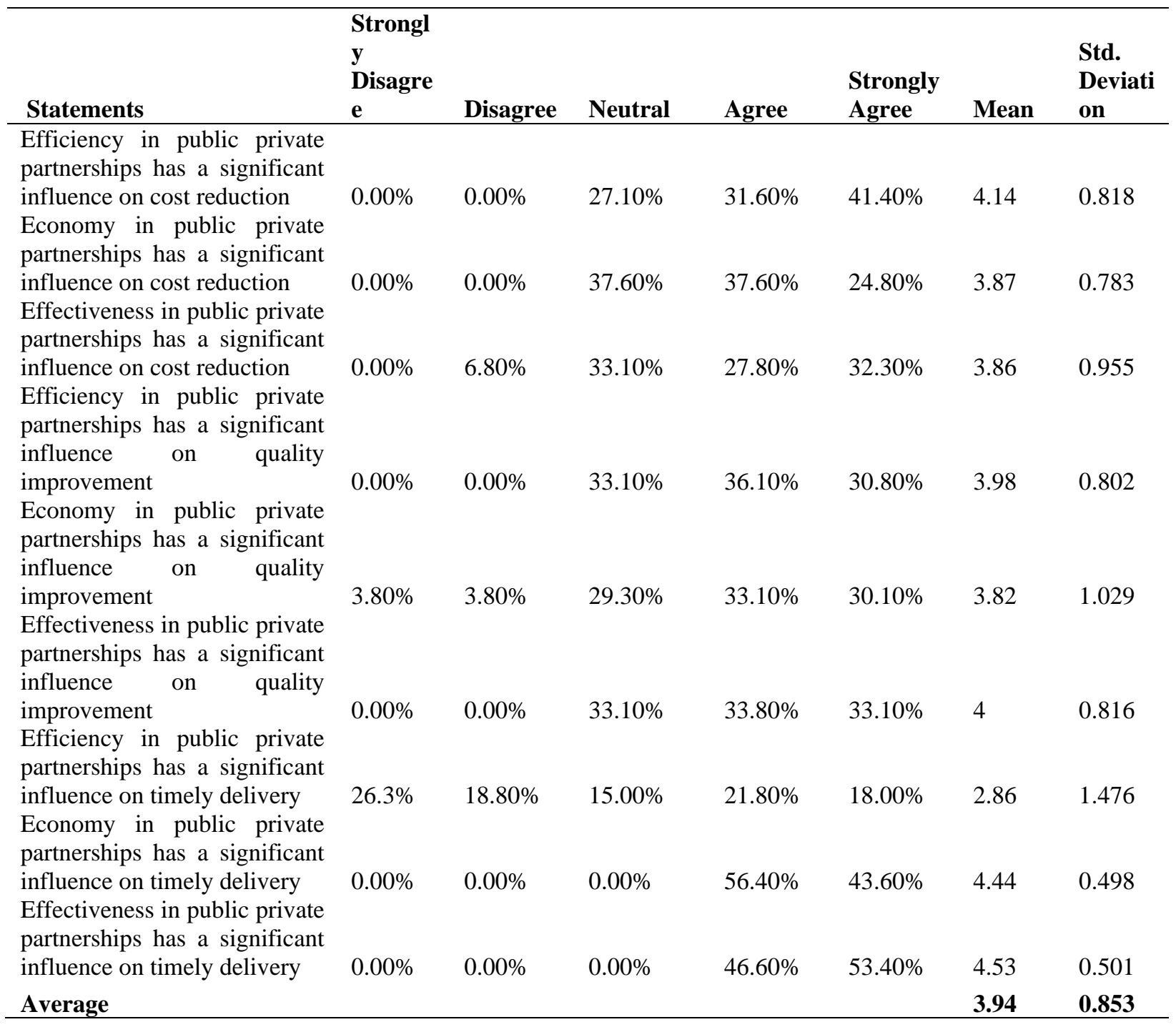

\subsubsection{Risk Mitigation}

The last objective of the study was to determine the influence of risk mitigation on performance of projects among state corporations in Kenya. The respondents were asked to indicate to what extent risk mitigation influenced performance public private partnership projects in Kenya. Results indicated that majority of the respondents $48 \%$ agreed that it was very effective, $44 \%$ said that it was effective, $5 \%$ said it was ineffective, while somehow effective was at $3 \%$. 
International Journal of Supply Chain and Logistics

ISSSN 2520-3983 (Online)

Vol. 4, Issue No.2, pp 52 - 79, 2020

www.carijournals.org

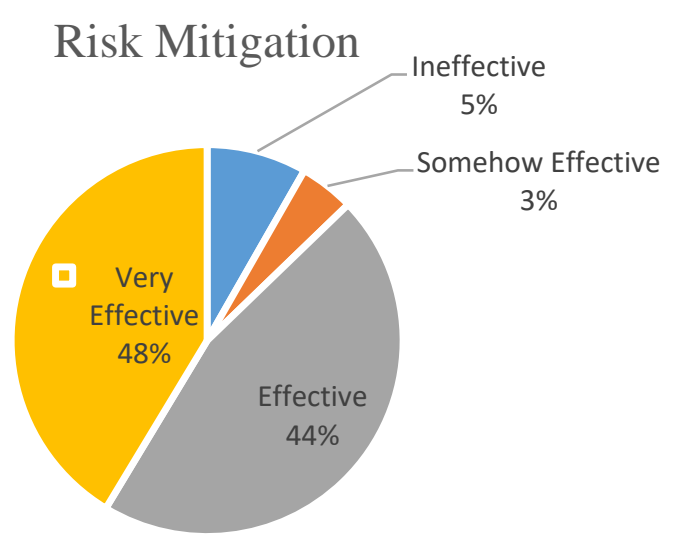

Figure 8: Risk Mitigation

The respondents were also asked to comment on statements regarding risk mitigation influenced performance of public private partnership projects in Kenya. The respondents were asked to indicate descriptive responses for risk mitigation. The result in table 6 revealed that majority of the respondents as indicated by a mean of (3.98) indicated that they agreed with the statement that risk identification has a significant influence on cost reduction. The responses were varied as measured by standard deviation of 0.83 . The result revealed that majority of the respondents as shown by a mean of (3.9) indicated that they agreed with the statement that risk classification and quantification has a significant influence on cost reduction. The responses were varied as measured by standard deviation of 0.815 . The result revealed that majority of the respondents with a mean of (4.05) indicated that they agreed with the statement that risk monitoring and review has a significant influence on cost reduction. The responses were varied as measured by standard deviation of 0.847 .

The result revealed that majority of the respondents (4.46) indicated that they agreed with the statement that risk identification has a significant influence on quality improvement. The responses were varied as measured by standard deviation of 0.5 . The result revealed that majority of the respondents (4.58) indicated that they agreed with the statement that risk classification and quantification have a significant influence on quality improvement. The responses were varied as measured by standard deviation of 0.496 . The result showed that majority of the respondents (2.99) indicated that they agreed with the statement that risk monitoring and review has a significant influence on quality improvement. The responses were varied as measured by standard deviation of 1.459 .

The result revealed that majority of the respondents as shown by a mean of (2.96) indicated that they agreed with the statement that risk identification has a significant influence on reducing delivery time. The responses were varied as measured by standard deviation of 1.489. The result revealed that majority of the respondents with a mean of (3.56) indicated that they agreed with the statement risk classification and quantification has a significant influence on reducing delivery time. The responses were varied as measured by standard deviation of 1.117 . The result revealed 
that majority of the respondents (3.71) indicated that they agreed with the statement that risk monitoring and review has a significant influence on reducing delivery time. The responses were varied as measured by standard deviation of 1.07. The average response for the statements on risk mitigation was 3.79. The findings agree with Marques (2011) that exemplary risk mitigationis necessary for the performance of public private partnerships projects.

Table 6: Risk Mitigation

\begin{tabular}{|c|c|c|c|c|c|c|c|}
\hline Statements & $\begin{array}{l}\text { Strongly } \\
\text { Disagree }\end{array}$ & $\begin{array}{l}\text { Disagre } \\
\text { e }\end{array}$ & Neutral & Agree & $\begin{array}{l}\text { Strongly } \\
\text { Agree }\end{array}$ & Mean & $\begin{array}{l}\text { Std. } \\
\text { Deviation }\end{array}$ \\
\hline $\begin{array}{l}\text { Risk identification has a } \\
\text { significant influence on cost } \\
\text { reduction }\end{array}$ & $0.00 \%$ & $0.00 \%$ & $35.30 \%$ & $31.60 \%$ & $33.10 \%$ & 3.98 & 0.83 \\
\hline $\begin{array}{llr}\text { Risk classification and } & \text { andification has a } \\
\text { quantion }\end{array}$ & & & & & & & \\
\hline $\begin{array}{l}\text { significant influence on cost } \\
\text { reduction } \\
\text { Risk monitoring and review }\end{array}$ & $0.00 \%$ & $0.00 \%$ & $38.30 \%$ & $33.10 \%$ & $28.60 \%$ & 3.9 & 0.815 \\
\hline $\begin{array}{l}\text { Risk monitoring and review } \\
\text { has a significant influence on } \\
\text { cost reduction }\end{array}$ & $0.00 \%$ & $0.00 \%$ & $33.10 \%$ & $28.60 \%$ & $38.30 \%$ & 4.05 & 0.847 \\
\hline $\begin{array}{l}\text { Risk identification has a } \\
\text { significant influence } \\
\text { quality improvement } \\
\text { Risk classification } \\
\end{array}$ & $0.00 \%$ & $0.00 \%$ & $0.00 \%$ & $54.10 \%$ & $45.90 \%$ & 4.46 & 0.5 \\
\hline $\begin{array}{l}\text { quantification has a } \\
\text { significant influence on } \\
\text { quality improvement } \\
\text { Risk monitoring and review }\end{array}$ & $0.00 \%$ & $0.00 \%$ & $0.00 \%$ & $42.10 \%$ & $57.90 \%$ & 4.58 & 0.496 \\
\hline $\begin{array}{l}\text { has a significant influence on } \\
\text { quality improvement }\end{array}$ & $21.8 \%$ & $20.3 \%$ & $15.00 \%$ & $22.60 \%$ & $20.30 \%$ & 2.99 & 1.459 \\
\hline $\begin{array}{l}\text { Risk identification has a } \\
\text { significant influence on } \\
\text { reducing delivery time } \\
\text { Risk classification and }\end{array}$ & $24.1 \%$ & $17.3 \%$ & $19.50 \%$ & $16.50 \%$ & $22.60 \%$ & 2.96 & 1.489 \\
\hline $\begin{array}{l}\text { quantification has a } \\
\text { significant influence on } \\
\text { reducing delivery time } \\
\text { Risk monitoring and review }\end{array}$ & $0.00 \%$ & $24.1 \%$ & $21.10 \%$ & $29.30 \%$ & $25.60 \%$ & 3.56 & 1.117 \\
\hline $\begin{array}{l}\text { has a significant influence on } \\
\text { reducing delivery time }\end{array}$ & $0.00 \%$ & $18.0 \%$ & $21.10 \%$ & $32.30 \%$ & $28.60 \%$ & 3.71 & 1.07 \\
\hline Average & & & & & & 3.79 & 0.958 \\
\hline
\end{tabular}


International Journal of Supply Chain and Logistics

ISSSN 2520-3983 (Online)

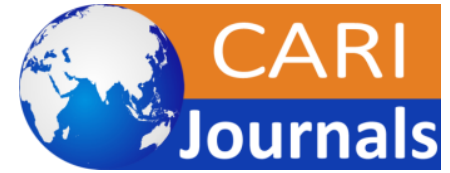

Vol. 4, Issue No.2, pp 52 - 79, 2020

WwW.carijournals.org

\subsection{Correlation Analysis}

Correlation analysis was used to determine both the significance and degree of association of the variables and also predict the level of variation in the dependent variable caused by the independent variables. The results of the correlation analysis are summarized in Table 7.

Table 7: Summary of Pearson's Correlations

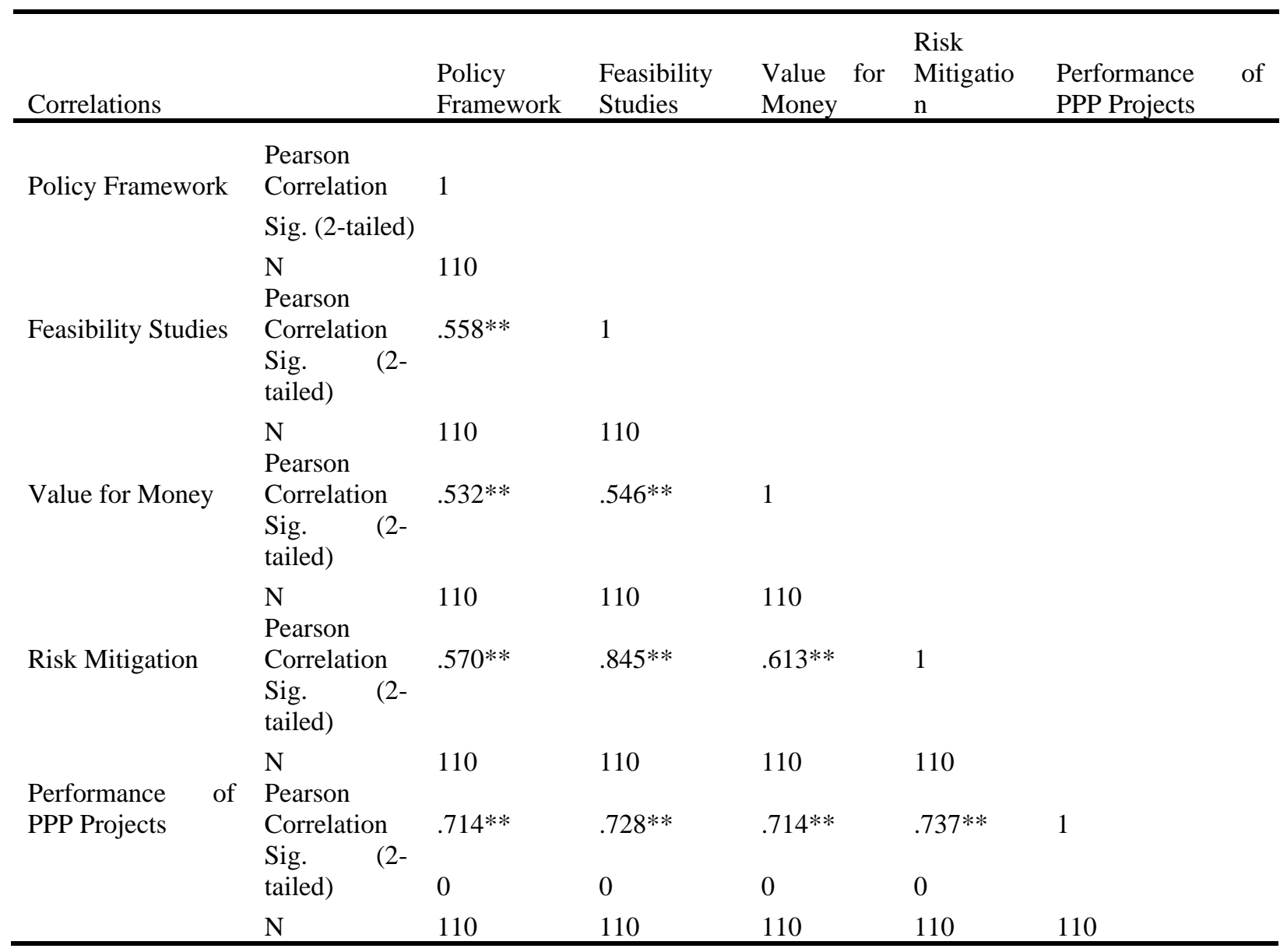

** Correlation is significant at the 0.05 level (2-tailed).

The correlation summary shown in Table 7 indicated that the associations between each of the independent variables and the dependent variable were all significant at the $95 \%$ confidence level. The correlation analysis to determine the association between policy framework and performance of public private partnerships projects among state corporations in Kenya, Pearson correlation coefficient computed and tested at 5\% significance level. The results indicate that there was a positive relationship $(\mathrm{r}=0.714)$ between policy framework and performance of public private partnerships projects among state corporations in Kenya. In addition, the researcher found the relationship to be statistically significant at $5 \%$ level $(\mathrm{p}=0.000,<0.05)$. 
International Journal of Supply Chain and Logistics

ISSSN 2520-3983 (Online)

Vol. 4, Issue No.2, pp 52 - 79, 2020

WWW.carijournals.org

The correlation analysis to determine the relationship between feasibility studies and performance of public private partnerships projects among state corporations in Kenya, Pearson correlation coefficient computed and tested at 5\% significance level. The results indicated that there was a positive relationship $(\mathrm{r}=0.728)$ between feasibility studies and performance of public private partnerships projects among state corporations in Kenya. In addition, the researcher found the relationship to be statistically significant at $5 \%$ level $(\mathrm{p}=0.000,<0.05)$.

The correlation analysis to determine the relationship between values for money and performance of public private partnerships projects among state corporations in Kenya, Pearson correlation coefficient computed and tested at 5\% significance level. The results indicate that there was a positive relationship $(\mathrm{r}=0.714)$ between value for money and performance of public private partnerships projects among state corporations in Kenya. In addition, the researcher found the relationship to be statistically significant at $5 \%$ level $(\mathrm{p}=0.000,<0.05)$.

The correlation analysis to determine the relationship between risk mitigation and performance of public private partnerships projects among state corporations in Kenya, Pearson correlation coefficient computed and tested at 5\% significance level. The results indicate that there was a positive relationship $(\mathrm{r}=0.737)$ between risk mitigation and performance of public private partnerships projects among state corporations in Kenya. In addition, the researcher found the relationship to be statistically significant at $5 \%$ level $(\mathrm{p}=0.000,<0.05)$.

\subsection{Regression Analysis}

In this study multivariate regression analysis was used to determine the significance of the relationship between the dependent variable and all the independent variables pooled together. Regression analysis was conducted to find the proportion in the dependent variable (performance of projects) which can be predicted from the independent variables (policy framework, feasibility studies, value for money and risk mitigation). Table 8 presented the regression coefficient of independent variables against dependent variable. The results of regression analysis revealed there was a significant positive relationship between dependent variable and the independent variable.

The independent variables reported $\mathrm{R}$ value of 0.796 indicating that there was perfect relationship between dependent variable and independent variables. The coefficient of determination also called the $\mathrm{R}^{2}$ was 0.634 . $\mathrm{R}^{2}$ value of 0.634 means that $63.4 \%$ of the corresponding variation in performance of PPP projects can be explained or predicted by (policy framework, feasibility studies, value for money and risk mitigation) which indicated that the model fitted the study data. The results of regression analysis revealed that there was a significant positive relationship between dependent variable and independent variable at $(\beta=0.634), p=0.000<0.05)$.

Table 8: Model Summary

\begin{tabular}{lllll}
\hline Model & R & R Square & Adjusted R Square & $\begin{array}{l}\text { Std. Error of the } \\
\text { Estimate }\end{array}$ \\
\hline 1 & $0.796^{\mathrm{a}}$ & 0.634 & 0.622 & 0.203452 \\
\hline
\end{tabular}


International Journal of Supply Chain and Logistics

ISSSN 2520-3983 (Online)

Vol. 4, Issue No.2, pp 52 - 79, 2020

wWw.carijournals.org

Table 9: ANOVA

\begin{tabular}{|c|c|c|c|c|c|c|}
\hline Model & & $\begin{array}{l}\text { Sum } \\
\text { Squares }\end{array}$ & of $\mathrm{df}$ & Mean Square & $\mathbf{F}$ & Sig. \\
\hline \multirow[t]{2}{*}{1} & Regression & 9.167 & 4 & 2.292 & 45.84 & $.000^{\mathrm{b}}$ \\
\hline & $\begin{array}{c}\text { Residual } \\
\text { Total }\end{array}$ & $\begin{array}{l}5.298 \\
14.465\end{array}$ & $\begin{array}{l}105 \\
109\end{array}$ & 0.050 & & \\
\hline
\end{tabular}

The significance value is 0.000 which is less than 0.05 thus the model is statistically significance in predicting how policy framework, feasibility studies, value for money and risk mitigation influence performance of public private partnership projects in Kenya. The F critical at 5\% level of significance was 25.65. Since F calculated which can be noted from the ANOVA table above is 45.84 which is greater than the F critical (value $=25.65$ ), this shows that the overall model was significant. The study therefore establishes that; policy framework, feasibility studies, value for money and risk mitigation influence performance of public private partnership projects. These results agree with Jooste (2011) results which indicated a positive and significant influence of policy framework, feasibility studies, value for money and risk mitigation on performance of projects.

Table 10: Coefficients of Determination

\begin{tabular}{|c|c|c|c|c|c|}
\hline \multirow[t]{2}{*}{ Model } & \multicolumn{2}{|c|}{$\begin{array}{l}\text { Unstandardized } \\
\text { Coefficients }\end{array}$} & \multirow{2}{*}{$\begin{array}{c}\begin{array}{c}\text { Standardized } \\
\text { Coefficients }\end{array} \\
\text { Beta } \\
\end{array}$} & \multirow[t]{2}{*}{$\mathbf{t}$} & \multirow[t]{2}{*}{ Sig. } \\
\hline & $\beta$ & Std. Error & & & \\
\hline 1 (Constant) & 1.967 & 0.218 & & 9.022 & 0.000 \\
\hline Feasibility Studies & 0.358 & 0.049 & 0.568 & 7.327 & 0.000 \\
\hline Policy Framework & 0.132 & 0.056 & 0.152 & 2.364 & 0.000 \\
\hline Value for Money & 0.121 & 0.032 & 0.27 & 3.835 & 0.020 \\
\hline Risk Mitigation & 0.05 & 0.05 & 0.074 & 0.998 & 0.030 \\
\hline
\end{tabular}

a. Predictors: (Constant), Policy Framework, Feasibility Studies, Value for Money and Risk Mitigation

b. Dependent Variable: Performance of PPP Projects

The research used a multiple regression model

$Y=\beta_{0}+\beta_{1} X_{1}+\beta_{2} X_{2}+\beta_{3} X_{3}+\beta_{4} X_{4}+\varepsilon$

Where:

$\mathrm{Y}=$ Performance of PPP Projects

$\beta \mathrm{o}=$ Constant Coefficient

$\mathrm{X}_{1}=$ Feasibility Studies

$\mathrm{X}_{2}=$ Policy Framework

$\mathrm{X}_{3}=$ Value for Money 
International Journal of Supply Chain and Logistics

ISSSN 2520-3983 (Online)

Vol. 4, Issue No.2, pp 52 - 79, 2020

$\underline{\text { www.carijournals.org }}$

$\mathrm{X}_{4}=$ Risk Mitigation

$\varepsilon=$ Random Error Term

The regression equation is;

$$
\mathrm{Y}=1.967+0.358 \mathrm{X}_{1}+0.132 \mathrm{X}_{2}+0.121 \mathrm{X}_{3}+0.05 \mathrm{X}_{4}
$$

The regression equation above has established that taking all factors into account (policy framework, feasibility studies, value for money and risk mitigation) constant at zero, performance of projects among state corporations will be an index of 1.967. The study found that a unit increase in feasibility studies will lead to a 0.358 increase in the performance of PPP projects among state corporations. The P-value was 0.000 and hence the relationship was significant since the p-value was lower than 0.05 .

The findings presented also shows that taking all other independent variables at zero, a unit increase in policy framework will lead to a 0.132 increase in the performance of PPP projects among state corporations. The P-value was 0.02 which is less 0.05 and thus the relationship was significant.

In addition, the study found that a unit increase in value for money will lead to a 0.121 increase in the performance of PPP projects among state corporations. The P-value was 0.000 and thus the relationship was significant because the p-value was less than 0.05 . The study also found that a unit increase in risk mitigation will lead to a 0.05 increase in performance of PPP projects among state corporations. The P-value was 0.03 , which is less than 0.05 and thus the relationship was significant.

\subsection{SUMMARY, CONCLUSION AND RECOMMENDATIONS}

\subsection{Summary of the Findings}

The study endeared to determine influence of public private partnerships on performance of projects among state corporations in Kenya. The regression results revealed that public private partnerships drivers identified in the study, that is, policy framework, feasibility studies, value for money and risk mitigation combined could explain approximately $63.4 \%$ of the variations in the performance of projects among state corporations. The other $36.6 \%$ may be attributed to other strategies not explained by the model or the variables.

\subsection{Conclusion}

Based on the study findings, the study concludes that performance of projects among state corporations can be improved by policy framework, feasibility studies, value for money and risk mitigation

\subsection{Recommendations}

The study recommended that public institutions should embrace public private partnerships so as to improve performance of projects among state corporations and further researches should to be carried out in other public institutions to find out if the same results can be obtained. 
International Journal of Supply Chain and Logistics

ISSSN 2520-3983 (Online)

Vol. 4, Issue No.2, pp 52 - 79, 2020

www.carijournals.org

\section{REFERENCES}

Abednego, M.P., \& Ogunlana, S. (2016). Good project governance for proper risk allocation in public private partnership in Indonesia. International jornal of project Management, 5(2), 622-634.

Abel-Aziz, A.M. (2017). Successful delivery of public-private partnership for Infrastructure Development. Journal of Consruction Engineering and Management, 5(1), 918-931.

Agree, S. (2010). Promoting good governance: Principles practice and perspective. Journal of commonwelth Secretariat, 2(2), 68-79.

Agresti, A. (2010). An Introduction to Categorical Data Analysis. John Wiley and Sons, Inc.: New York.

Akitonye, A., \& Chinyio, E. (2015). Private finance initiative in the health sector: Treads and risk assesment. Engineering, construction and architectual management, 6(3), 601-616.

Akitonye, A., Beck, M., \& Handcastle, C. (2013). Public private partnership-Managing risks and opportunities. Oxford University.

Alchian, A., \& Demsetz, H. (2011). Production, information cost and economic organisation. American Economic Review.

Algarni, A.M., Arditi, D., \& Polat, S. (2016). Build-Operate-Transfer in infrastructure projects in the United States. Journal of Construction Engineering and Management, 8(4), 728-735.

Anyaehie, U., Nwakoby, B., \& Chikwendu, C. (2014). Constrints, challenges and prospects of public private partnership in healthcare delivery in a developing economy. Ann Med Health Science Research.

Aoust, J.M., Bennett, T.C., \& Fiszelson, R. (2010). Risk analysis and sharing: the key to successful public-private partnership. Financing major infrastructure and public service projects, 4(1), 57-80.

Arndt, R. (2013). Optimal risk transfer in Build-Own-Operate-Transfer projects: the challenge for governments. Journal of transations of multi-displinary Engineering Australia, 9(2), 1-8.

Associate, M.N. (2017). Key challenges of Public Private Partnership in South africa. Castalia Ltd.

Bank, W. (2008). Private participation in infrastructure (PPI) projects database, available at http://ppi.worldbank.org.

Bing, L., Akintonye, A., Edwards, P.J., \& Hardcastle, C. (2014). Critical success factors for PPP/PFI projects in the UK construction industry. Journal of Construction management and Economics, 9(2), 459-471.

Bovaird, T. (2014). Public-Private Partnership: from contested concept to prevalent practice. International review of Administrative sciences. 
International Journal of Supply Chain and Logistics

ISSSN 2520-3983 (Online)

Vol. 4, Issue No.2, pp 52 - 79, 2020

$\underline{\text { www.carijournals.org }}$

Bovis, C. (2013). Public Private Partnership. In Bovis, Public Private Partnership. Oxon.

Boyer, E.J., Van-Slyke, D.M., \& Roger, J.D. (2016). An Empirical examination of public involvementin public-private partnership: Qualifying the benefit of of public involvement in PPP. Journal of Public Administration Research and Theory, 7(1), 45-61.

Brabham, D.C. (2010). Crowdsourcing: A model for leveraging online communities. The Routledge handbook of participatory cultures, 3(2), 120-129.

Brown, T.L., Potoski, M., \& Van Slyke, D.M. (2016). Managing public service contracts. Alining values, Institutions and markets. Public Administration Review.

Burger, P., \& Hawkesworth, I. (2011). How to attain value for money: Comparing PPP and traditional infrastructure public procurements. OECD Journal on Budgeting, 5(2), 1-56.

Buxbaum, J.N., \& Ortiz, I.N. (2007). Protecting public interest: the role of Long-term Consessin agreements for providing transport infrastructure. Los Angles: University of California.

Callender, G., Jamieson, D., \& Vincent, K. (2014). Software costing analysis model for evaluationg value for money. Challenges in Public Procurement: an International perspective, 2(2), 81-103.

Chan, A.P.C., Yeung, J.F.Y., Yu. C.C.P., Wang, S.Q. \& Ke,Y. (2011). Empirical study of risk assessment and allocation of public-partnership projects in China. ASCE Journal of Management in Engineering, 9(2), 136-148.

Chan, D.M., Chan, A. C., \& Lamu, P.T. (2016). A feasibiliy study of the implementation of Public Private Partnership. Hong Kong: Hong Kong Polytechic university.

Chege, L. W. (2011). Private financing of construcion projects and procurement systems. NewZealand.

Clarke, T. (2014). Theories of corporate governance: The philosophical foudation of corporate governance. New Yolk: Taylor and Francis Group.

Cooper, D. (2016). Business Research Methods, Business Research Methods. McGrraw Hill.

Corbett, P., \& Smith, R. (2016). An analysis of the private finance initiative as the government preferred procurement route. UK: University of Wolverhampton.

Cummining, D. (2008). Government policy towards entrepreneurial finance, Innovation investment fund. Journal of business venturing, 5(2), 193-235.

Dada, M.O. (2009). A survey for the public-private partnership in Nigerian construction procurement projects. Journal for centre for research and innovation, 6(1), 426-442.

Dehli, V.S.K., Palukuri, S., \& Mahalingram, A. (2010). Governance issues in ublic private partnership in infrustructure projects in India. Journal of Engineering Project, 3(1), 426442. 
International Journal of Supply Chain and Logistics

ISSSN 2520-3983 (Online)

Vol. 4, Issue No.2, pp 52 - 79, 2020

www.carijournals.org

De-Vries, P. (2013). The Routledge companionto public private partnership. The Routledge companionto public private partnership. New Yolk: Routledge.

Dunn, S. D. (2010). Statistics and Data analysis for the Behavioral Science: McGraw Hill.

Freeman, R.E., Harrison, J.S., Wicks, A.C., Parmar, B., \& De Colle, S. (2010). Stakeholder Theory. Stakeholder Theory. New Yolk: Cambridge Press.

Garvin, M. J. (2010). Enabling development of the transportation public private partnership market in the United States. Journal of Construction Engineering and Management, 3(1), 402411.

George, D., \& Mallery, P. (2013). SPSS for Windows step by step: A simple guide Longman Publishers, Nairobi, Kenya Debt structure [Electronic Version].

Glendinning, R. (2010). Concept of value for money. International Journal of Public Sector Management, 4(1), 42-50.

Grimsey, D. (2015). Are public private partnership value for money? Evaluating alternative approaches and comparing academic and practitioner views. Journal of Public Administration, 3(2), 345-378.

Gruneberg, S., Hughes, W. \& Ancell, C. (2007). Risk under performance based contracting in the UK constructionsector. Journal of Construction Management and Economics, 6(1), 691699.

Hartman, F., \& Snelgrove, P. (2016). Risk allocation in lumpsum contracts; concept of latent dispute. Journal of construction and Engineering Management, 3(1), 291-296.

Hayford, O. (2016). Successfully allocating risk and negociating a PPP contract. Proceeding of the 6th annual national public private partnership summimit which way for australia's PPP market .

Henjewele, C.S. (2011). Critical parameter influencing value for money variation in FPI projects in the healthcare and transport sector. Journal of Construction and Management, 5(1), 825839.

Ho, S.P. (2016). Model for financing renegotiation in public private partnership projects and its policy implication. Journal of Contractuction Engineering and management, 3(2), 678668.

Hodge, G.A. (2009). Delivering Performance Improvements Through Private Partnership. Defining and Evaluating Phenomenon .

Hodge, G.A. Greve, C., \& Broardman, A. E. (2010). International handbook on public private partnership. International handbook on public private partnership. Edward Elgar.

Hui, S.Y. (2010). Value for money test in infrastructure procurement, 9(1), 549-553. 
International Journal of Supply Chain and Logistics

ISSSN 2520-3983 (Online)

Vol. 4, Issue No.2, pp 52 - 79, 2020

www.carijournals.org

Hwang, B.G., \& Zhao, X. (2013). Public Private Partnership projects in Singapore: factors, critical risk and preferred risk allocation from the perspective of contractors. International journal of project management, 3(1), 424-433.

investment and finance, 6(2), 363-373.

Isaac, S., \& Michael, W. (2015). Handbook in Research and Evaluation for Education and the Behavioral Sciences. Macdonald and Evans, Ohio, U.S.A.

Ismail, S. (2013). Critical success factors for public private partnership implementation in Malaysia. Journal of Business Administration, 5(2), 6-19.

Jackson, J. (2010). Examining Tunnel vision in Australian PPP: Rationales,rhetoric risks and rogues. Australian Journal od Public Administration, 4(1), 61-73.

Jackson, P. (2014). Value for money and international development. Journal of OECD Development, 5(1), 51-73.

Jin, X. H. (2010). Determinats of efficient risk allocation in privately financed public infrastructure projects in Australia. ASCE Journal of Construction Engineering and Management, 3(3), $138-150$.

Jin, X.H, \& Doloi, H. (2008). Interpreting risk allocation mechanism in public private partnership projects. An empirical study in a transation cost economics perspective Consruction Management and Economics.

John, G., \& Johnson, P. (2012). Research methods for Managers, 4th Edition. Sage Publications: London.

Jooste, S. F. (2011). Beyound one size fits all: How local conditions shape PPP enabling field development. Engineering Project Organisation Journal, 3(3), 11-25.

Kasomo, D. (2011). Research Methods in Humanities and Education, Eldoret; Zapf Chancery. Kenya, Long term plan 2015-2035. Nairobi: Ministry of Energy and Petroleum.

Kombo, D. \& Tromp, D. (2013). Proposal and Thesis Writing, an introduction. Nairobi: Pauline Publications Africa.

Kothari, C. R. (2014). Research Methodology; Methods \& Techniques (2nd ed.). New Delhi; New Age International Press Limited.

Kusljic, D., \& Marenjak, S. (2013). Critical PPP/PFI projects sucess criteria for public sector clients. Princeton University Press

Kweit, M. G. (2012). The politics of policy analysis: the role of citizen participation in analytic decision making. Plicy studies review.

Laffont, J. J., \& Martimort, S. (2012). The theory of Incentives. The theory of Incentives:the principle-agent model. Princeton University Press. 
International Journal of Supply Chain and Logistics

ISSSN 2520-3983 (Online)

Vol. 4, Issue No.2, pp 52 - 79, 2020

$\underline{\text { www.carijournals.org }}$

Lakomy-Zinowik, M. (2017). Public-private partnership as na alternative source of financeing of public task. Retrieved from htt://dx.doi.org/10.12775/Eip.2017.

Li, B., Akintoye, A., Edwards, P.J., \& Hardcastle, C. (2015). Critical success factors for PPP/PFI projects in the UK construction industry. Journal of construction management and economics, 7(3), 707-721.

Liu, J., Love, P., Davis, P., Smith, J., \& Regan, M. (2014). Conceptual framework for the performance measurements of Public-private partnerships. Journal of infrastructure systems, 4(3), 21-34.

Maguire, G., \& Malinovitch, A. (2010). Developments of PPP in Victoria. Australian Accouting Review, 8(3), 27-33.

Marques, R. (2011). Risks, contracts, and private sector participation in infrustructure. ASCE Journal of Construction Enginneering and Management, 5(2), 925-932.

Meng, X., Zhao, Q., \& Shen, Q. (2011). Critical success factors for transfer-operate-transfer urban water supply projects in China. ASCE Journal of Management in Enginneering, 3(1), 243251.

Montanheiro, L. (2008). Public private partnership and their economic contribution. International Journal of Applied Public-Private Partnership, 3(3), 1-18.

Moralos, D. (2008). A state of practice of value for money analysis in comparing public private partnership to traditional procurements. Journal of Public Works Management Policy, 5(2), 925-932.

Mugenda, O.M., \& Mugenda, A.G. (2012). Research Methods: 1st Edition, Published by ACTS, Nairobi, Kenya.

Mwaengo, L.M. (2012). Public privte partnership strategic implementation an intiative of the municiple council of Mombasa. UON.

Neuman, W.L. (2010). Social Research Methods: Qualitative and Quantitative Approaches (Fourth Edition ed.) Boston.

Ng, A., \& Loosemore, M. (2007). Risk allocation in the private provision of public infrastructure. International Journal of Public Management, 3(2), 66-76.

Ng, S.T., Wong, Y.M.W., \& Wong, J.M.W. (2012). Factors influencing the sucess of PPP at feasibility stage. Habitat International.

Ngechu, M. (2009). Understanding the Research Process and Methods. An Introduction to Research Methods. Acts press, Nairobi.

OECD. (2008). Public Private Partnerships: in pursuit of risk sharing and value for money. Paris: Organisation for economic co-operation and development publishing.

Ogula, P. (2015). Research Methods. Nairobi: CUEA Publications. 
International Journal of Supply Chain and Logistics

ISSSN 2520-3983 (Online)

Vol. 4, Issue No.2, pp 52 - 79, 2020

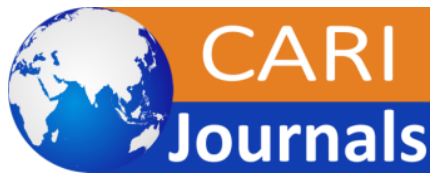

www.carijournals.org

Ojo, S.O. (2009). Benchmarking the performance of construction procurements methods aganist selection creteria in Nigeria. Civil Engineering Dimension.

Orodho, C.R. (2010). Element of Education and Social Sciences. Research Methods 2nd Edition, Kanezja Publishers, New Delhi. 